\title{
El papel educativo de la formación informal en la creación de un modelo empresarial de nuevos negocios
}

\section{The educational role of informal training in creating Anentrepreneurial model of new business}

\author{
Ghadir Fakher, ${ }^{1 a}$ Fereydoon Azma, ${ }^{2}$ Samereh Shojaei $^{3} \&$ Mahmoud Reza Mostaghimi ${ }^{4}$ \\ Department of entrepreneurship, \\ Aliabad Katoul Branch, Islamic Azad University, \\ Aliabad Katoul, Iran ${ }^{1234}$ \\ (iD) ORCID ID: https://orcid.org/0000-0003-0020-6175 \\ iD ORCID ID: https://orcid.org/0000-0003-1414-8535 \\ (iD) ORCID ID: https://orcid.org/0000-0002-7605-318X \\ iD ORCID ID: https://orcid.org/0000-0001-9742-179X
}

\begin{abstract}
Resumen
El desarrollo del emprendimiento empresarial es importante para cualquier negocio. El propósito de este estudio es presentar un modelo empresarial para start-ups enfocado en el impacto de la innovación y la educación no formal. El presente modelo de investigación examina el papel de la formación informal en el rendimiento empresarial y la estimación de las expectativas del cliente. El modelo teórico derivado se probó en 100 datos de empresas emergentes en Irán. El análisis PLS-SEM mostró que la educación no formal afectó directamente el desempeño de las empresas. Los resultados mostraron que el capital humano es uno de los determinantes de la educación no formal. El efecto mediador de la formación informal y la estimación de las expectativas del cliente sobre la relación entre la calidad de RR.HH. y el rendimiento empresarial fue bastante evidente.
\end{abstract}

Palabras clave: modelo de emprendimiento, educación no formal, desempeño empresarial, innovación, capital humano

\author{
Abstract \\ ${ }^{\mathrm{a} C}$ Correspondencia al autor \\ E-mail: maharat.azmoon@gmail.com
}


Entrepreneurship development is important for any business. The purpose of this study is to present an entrepreneurial model for start-ups focused on the impact of innovation and non-formal education. The present research model examines the role of informal training on business performance and customer expectation estimation. The derived theoretical model was tested on 100 startup business data in Iran. The PLS-SEM analysis showed that non-formal education directly affected the performance of businesses. Findings showed that human capital is one of the determinants of non-formal education. The mediating effect of informal training and customer expectation estimation on the relationship between HR quality and business performance was quite evident.

Keywords: Entrepreneurship Model, Non-formal Education, Business Performance, Innovation, Human Capital

\section{Introduction}

Innovation is one of the key components of entrepreneurship when considering small independent businesses as business owners as well (Jogaratnam, Tse and Olsen, 1999). Innovation Entrepreneurship Theory identifies entrepreneurs as a key driver of economic development through the introduction of innovation (Schumpeter, 2010). Therefore, entrepreneurs develop new innovations by creating new products or methods of production, opening new markets or new materials, and creating new organizational structures in the industry. At the same time, this situation changes the market and creates a competitive advantage (Herbert and Link 2006).

Entrepreneurship theories also illustrate the role of "human resources" in influencing business innovation and financial performance (Kellermanns et al., 2016). The quality of human resources is related to the amount of individual knowledge, skills and abilities of training and work-related experiences (Bakker et al., 2016). Endogenous Growth Theory (Nelson and Phillips, 1966) is based on the belief that increasing levels of education enables one to apply innovations more rapidly because they enhance the ability to perceive, evaluate and distinguish between promising and reckless ideas. Increase. Thus, when business owners increase the quality of their human resources, it enhances their cognitive abilities, enabling them to understand and exploit beneficial innovation that leads to improved business performance. (Davidsonand Honig, 2003). In addition, self-efficacy theory (Bandura, 1997) argues that learning from past experience is the most important factor in building higher beliefs in one's abilities. 
In the exploratory studies it was concluded that the entrepreneurship education system in Iran was no exception and had no coherent policy-making system. The desired form is not implemented and there is no reference or procedure for monitoring the proper implementation of these policies. Given the impact and scope of these major decisions, this study expands existing knowledge by empirically examining a conceptual model of entrepreneurship development and demonstrates the network of communication between innovation, non-formal education, human capital, and business performance. From a practical perspective, this research allows business owners to identify missing business loops and entrepreneurship training capabilities that lead to business success.

\section{Theoretical Framework}

Based on the literature on innovation and entrepreneurship management, this study adopts a comprehensive and integrated framework for examining performance drivers in start-ups. Understanding some of the characteristics of startups requires a "value chain model" approach. The value chain of corporations is a causal system that is interconnected by a chain (Prather and Millar, 1985). The value chain model transforms a business into two related and valuable strategic activities: initial and supportive activities. Initial activities include physical product creation, marketing and delivery of these products to buyers and support and after-sales service. Support activities are inputs that can perform initial activities that include inputs in the form of purchasing, human resources, technologies, and corporate structure (Prater and Millar,1985). In this study, we emphasize that corporate innovation activities, as well as informal education and quality of human resources, are critical elements of a value chain in business. These elements are incorporated throughout the company's valuation activities. These factors can also influence support activities by introducing new purchasing solutions or innovative ways of managing human resources. Likewise, informal training and improving the quality of human resources affect the performance of causal activities, dependent on the value chain of the company.

Figure 1 provides an integrated conceptual model of business performance. This model has four main theories of entrepreneurship and social psychology (Bandura,1997), entrepreneurship innovation theory (Schumpeter, 1952), human resource quality improvement theory (Nafukho, Hairstonand Brooks 2004), and endogenous growth theory (Nelson and Phelps, 1966). Through this approach, our proposed model examines predictors of business performance and causal 
network relationships. The performance of start-ups and innovation activities are presented as reflective hidden structures, which will be observed by proprietary indicators, respectively. Nonformal education has been shown to be a molecular model. Human capital is regarded as a constructive structure.

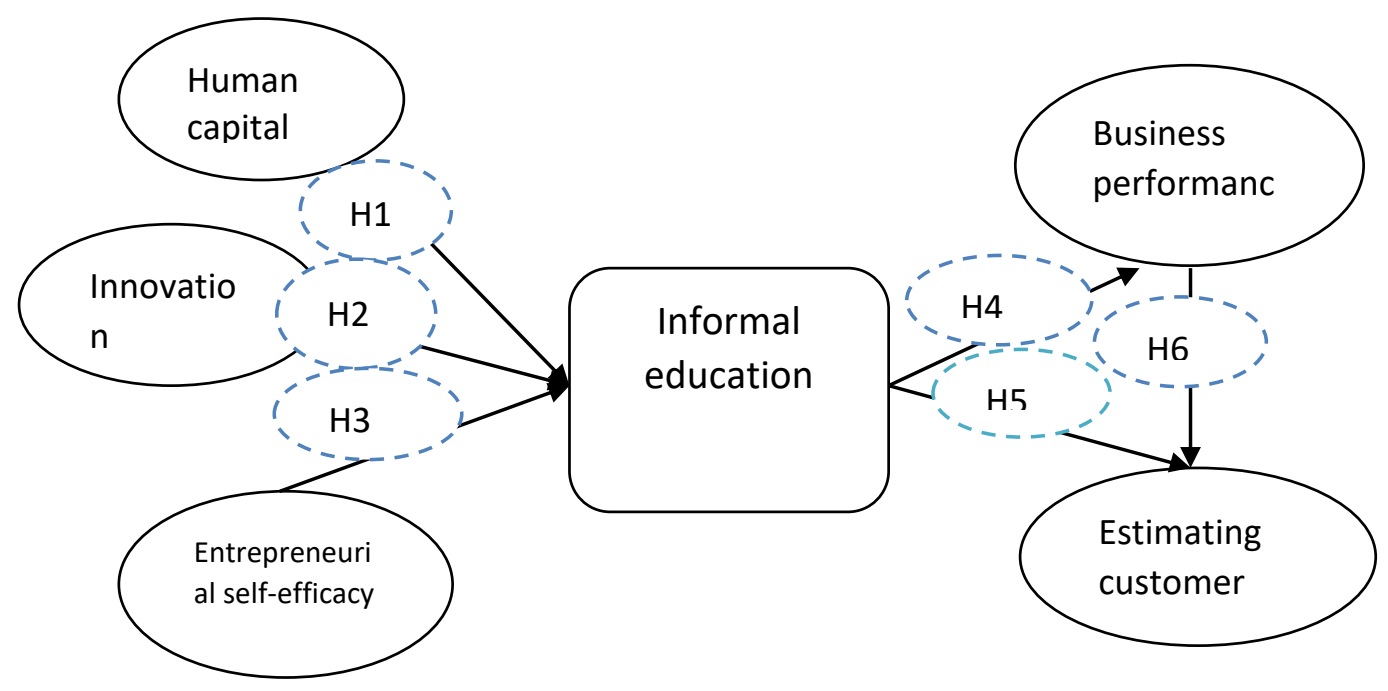

Fig. 1: An integrated conceptual model of the new business performance (startups).

\section{Non-formal education}

The concept of non-formal learning is defined as the three terms formal education, nonformal education and non-formal learning. Formal education refers to all events that are intentionally planned, have a fixed time schedule, hierarchies, different levels and input requirements, and within. Training is provided. Non-formal education refers to all deliberately unplanned learning events in the organizational setting. Non-formal education does not include hierarchical characteristics, input requirements, and regular time schedules. From jobs, seminars and workshops to non-teaching they are toxic. Informal or unintentional learning that can occur on a daily basis. Learning is a less organized, informal, deliberate natural process, and may involve all activities in the family, workplace, and throughout one's life. Informal learning involves learning, self-learning through task accomplishment, and learning through observation, reflection, reading the book, and talking with colleagues. In other words, informal and unconscious daily processes that lead to competencies, informal learning. This learning is more random, and may be 
framed by the learner L not identifiable (Alonderienè,2010). Types of non-formal education include:

1- Distance education

2- Internet University

3- Private education

\section{Human Capital}

Small investments are created around the entrepreneur, and business outcomes cannot be understood without particular attention to the founder's role in the business (Cooper, GimenoGasconand Woo,1994). In the field of entrepreneurship, the level of knowledge, experience, and competence of the entrepreneur, through formal education, business experience, hands-on learning, and non-formal education, contribute to the formation of an entrepreneurial human capital (Davidson and Honig, 2003). Entrepreneurial level of "human capital" determines productivity and efficiency and can influence the entrepreneurial behavior and outcomes of the company (Davidson and Honig, 2003). The theory of human capital is that man is a type of capital that can be developed, and investing in human profitability (through education) enhances labor productivity (Nafukho et al., 2004). At the core of human capital theory is the assumption that individuals invest intentionally in education in preparation for joining the workforce (Nafukho et al., 2004). As a result, they enter the workforce with a higher level of knowledge and skill and result in higher pay in economic terms (Corley et al., 2019).

Empirical evidence supports the positive relationship between entrepreneurial human capital and organizational performance (Ottenbacher and Gnoth,2005). Higher education enables entrepreneurs to successfully manage the company, identify the right market, and be more prepared to provide external financing applications that are effective for economic growth (Ottenbacher and Gnoth, 2005). Experienced entrepreneurs working in a similar sector have more knowledge of technological and market opportunities that can be of great use. Therefore, they can formulate appropriate strategies to pursue these opportunities that enhance the firm's performance (Ottenbacher and Gnoth, 2005). A qualitative study by (Parsa et al., 2005) reported on the unsuccessful actions of start-up business owners. These startups closed in less than 12 months due to previous inexperience in the startup business. 
A study by (Parsa et al.,2005) shows that education is important for the performance of startups. Studies have shown that prior education in a field similar to the corporate product offerings provides entrepreneurs with a useful understanding of how to identify appropriate markets and succeed in corporate management (Ottenbacher and Gnoth, 2005). Therefore, no previous research has examined the relationship between human resources and the use of nonformal education.However, organizations and business units that rely on pre-existing human capital are more likely to use formal training systems. It forms the basis of the following hypothesis:

Hypothesis 1. The human capital of business owners is positively related to the use of nonformal education.

\section{Innovative activities}

Innovation plays an important role in entrepreneurship (Herbert and Link, 2006) and is defined as the process of creating new solutions in the generation, adoption and implementation of ideas, processes, new products or service (Moss-Kanter,1983). Innovations must be new and must be successfully implemented to obtain economic benefits (Rogers 2003). Theory of Entrepreneurial Innovation states that in a capitalist system, entrepreneurs, by employing indirect methods of labor, destroy existing economic structures and create new ones the Schumpeter called "creative destruction." In different industries, entrepreneurs, through their concepts, products, ideas and innovations, create new values and fundamentally change people's tastes, making it a critical factor in the evolutionary path of products. And cause competition. Experimental evidence suggests that innovation guides the performance of the business structure (Nambisan, Wright and Feldman,2019). Protecting service products through patents and copyrights is difficult so continuous product innovation is essential for service companies to prevent competitors from progressing (Rogers,2003). In addition, the implementation of new management structures, technology to improve operational efficiency, and new logistics and delivery systems enable service companies to compete with lower costs (Bustinza et al.,2019).

The exploitation of the innovation structure in previous research has limited the findings. For example, the innovation criterion used by (Agarwa, Erramilli and Dev,2003) was assessed on a scale $(1=$ strongly disagree $=5=$ strongly agree). Measured only one type of innovation (i.e., service innovation). Concentrated and using a perception-based measure, respondents were asked 
to rate their innovative activities against their competitors (in a seven-point Likert scale). (Liao and Tsai,2019) used the measures of innovative behaviors, which is difficult to use in all businesses.

To address these limitations, this study uses a comprehensive criterion-based innovation criterion that classifies innovations into product, service, process, management, and marketing (Hall,2009). Product and service innovations refer to new or significantly improved products or services such as the introduction of new materials, by-products, new components, or new features (Camisón and Monfort-Mir, 2012). Examples of these innovations in start-ups include new service systems. Process innovations point to behind-the-scenes changes aimed at increasing productivity and efficiency, such as new equipment or automation, more efficient production methods, or the use of new energy sources (Camisón and Monfort-Mir,2012). Managerial innovations include new approaches to organizational management, work organization or external relations such as new ways to organize internal collaboration, employee guidance and training, professional development and service rewards (Ottenbacherand Gnoth, 2005). Marketing innovations include new marketing techniques that include changes in product design, advertising strategies, pricing, and new relationships with other sectors such as government and regulatory systems, social organizations, or specific customers (Camisón and Monfort-Mir, 2012) No study has examined the relationship between business innovation and education, so the first hypothesis is defined as follows.

Hypothesis 2. Innovation activities are positively related to the use of non-formal education.

\section{Entrepreneurial self-efficacy}

Entrepreneurs have a major impact on the direction, framework, and performance of the small business (Hallak, Lindsay and Brown,2011). This influence is due to the argument that a small business enterprise is the evolution of the individual responsible, and the individual entrepreneur is regarded as the company (Lumpkin and Dess,1996). Therefore, understanding the role of the entrepreneur in relation to enterprise-level innovations seems important. Studies on small companies have also focused on the self-efficacy entrepreneurship structure (ESE) (Hallak,Assaker and Lee, 2015). ESE refers to an individual's belief in his / her ability to achieve entrepreneurial tasks (Fuller et al., 2018). These include: developing new products and market 
opportunities, creating an innovative environment, building investor relationships, defining the main goal, addressing unexpected challenges, and developing critical human resources (De Noble, Jung and Ehrlich,1999).

Previous studies, such as the work of (Hallak, Lindsay and Brown,2011) investigated the relationship between ESE and performance at the latent structural level and used the segmentation method to transform the ESE multidimensional structure into a hidden structure. This is required for the purposes of SEM analysis; however, aspects of HR training including the entrepreneur's ability to recruit and retain and train talented people to work in the company should be taken into account (De Noble, Jung and Ehrlich,1999). These two components are important skills of successful entrepreneurs (De Noble, Jung and Ehrlich,1999). In addition, the Entrepreneurship Theory of Innovation (Schumpeter, 1952) suggests that entrepreneurial firms can survive and thrive through the ability of persistent innovation entrepreneurship to train human resources and respond to changes in the dynamic behavior of competitors. (O'Dwyer, Gilmore and Carson,2009). Therefore, the capacity of start-up entrepreneurs to "new product development and market opportunities" can be a key driver of their business performance. However, research on how ESE is structured on human resource education is still unknown. Based on empirical evidence and self-learning theory (Bandura, 1997) the following hypothesis is presented.

\section{Hypothesis 3. The ESE of startups is positively associated with informal education.}

\section{Performance of startups}

Research on startups' performance focuses on state-owned companies and chain startups that measure corporate performance through stock market valuation (Choi et al., 2011). Stock market valuation is not available for start-ups and small businesses that make up $99 \%$ of the total business. Unlike corporate finance records that are often publicly available, independent small business records are inaccessible to researchers. Therefore, the use of subjective metrics, rather than objective ones, is common in small business research (Hallak, Lindsay and Brown,2011).

Human resources training can enhance the competitiveness and financial performance of organizations (Cancedda et al.,2018). Better information enables managers to make better decisions and this improves the performance of the organization (Lee, Hallak and Sardeshmukh, 2016). Available evidence indicates a positive relationship between informal training and organizational performance (Wolfson et al., 2018). Huselid(1995) found that there was a positive 
relationship between strategic training and organizational financial performance. In this regard, it is assumed that:

Hypothesis 4. There is a positive relationship between non-formal education and financial performance.

\section{Customer Satisfaction and Human Resource Training}

Achieving high levels of customer satisfaction (Avcikurt, Altay and Ilban,2011) quality of customer service (Budianto, 2019) and customer retention (Zhang et al., 2013) are important to the success of any business. Here, the use of non-formal education can improve the development of efficient forces and consequently improve customer satisfaction, as corporate differentiation based on customer characteristics requires forward-looking criteria (Kaplan and Norton, 2004) and traditional training systems. Customer satisfaction has a positive relationship (Currie, Tuck and Morrell,2015). In addition, service organizations are usually sensitive to external factors (Kim, Cho and Brymer,2013). Given that HR training can be used to focus on customer interests and thus facilitate the development and development of new products / services and transform fruitless relationships into profitable relationships (Narayanan and Kaplan, 2001) it is assumed that:

\section{Hypothesis 5. Non-formal education is positively related to customer satisfaction.}

\section{Customer satisfaction and business performance}

Service-profit chain theory describes a process in which the growth and profitability of firms (financial performance) is derived from customer loyalty, which is a direct result of customer satisfaction (Heskett and Sasser, 2010). However, evidence regarding the relationship between customer satisfaction and financial performance with some studies in which a positive relationship has been reported (Capiez and Kaya, 2004) and other studies in which a negative relationship has been reported (Tornow and Wiley, 1991). This may be due to the benefit that comes from communicating with the customer, while profits can also be obtained through intimate relationships. However, business survival is not possible without customer satisfaction (Chi and Gursoy, 2009), because customers are one of the key drivers of financial performance (Kim, Cho and Brymer,2013). In addition, customer satisfaction is positively correlated with the future (Banker, Potter and Srinivasan,2005) and financial performance of the organization (Chi and Gursoy, 2009). In this regard, it is assumed that: 
Hypothesis 6. There is a positive relationship between customer satisfaction and financial performance of the organization.

\section{Methodology}

The questionnaire was sent to 100 people responsible for the financial oversight of businesses. Responses were obtained from 35 individuals and 35 companies. The potential for non-response orientation was evaluated as a minimum because there was no difference between the initial responses and the subsequent responses to all the factors of the questionnaire. Respondents were male (70\%) and middle-aged with an average of 22 years of industry experience. Some answers were not received. List-based deletions of items that did not include performance data (equal to 5) reduced the sample of the present study to 27 companies. In order to show the uniformity of the results (Way et al., 2018), the modified structural model of this study was evaluated using a list-based deletion of 27 and average displacement of 35 . The close similarity between the standard direct effect methods and the important estimates (Table 4) and the fit indices (Table 1) shows that the list-based deletion does not significantly affect the findings presented in this study.

\section{Criteria and reliability assessment}

Customer satisfaction was assessed using three factors related to customer satisfaction criteria (Zhou, Brown, and Dev, 2009). Respondents were asked to describe how: 1) quality of service performance, 2) customer retention performance, and 3) customer satisfaction performance of their organizations over the past three months compared to their competitors. Response options ranged from 1 (much worse) to 5 (much better). The composite reliability estimate for the hidden variable of customer satisfaction in this study was 0.87 and the mean of variance extracted (AVE) by the hidden variable of customer satisfaction in this study was more than 0.50 (Table 2). Corporate performance was assessed using three factors related to financial performance criteria (Cadez and Guilding,2012). Respondents were asked to describe (on average) how (1) the return on capital, (2) profitability, and (3) the gross operating profit of their organization over the past three months compared to direct competitors. Response options ranged from 1 (much worse) to 5 (much better). The composite reliability estimate for the latent variable of financial performance in this study was 0.85 (Table 2). Non-formal education was assessed using 5 factors related to (Nami et al.,2017). Response options ranged from 1 (never) to 5 (often). In line with previous 
research, the mean scores of all 5 informal education factors were equal to or greater than the midpoint. In other words, mean factor scores were in the range of 3, and reported levels of sample application for each of these 5 factors ranged from 1 (never) to 5 (most). Finally, in order to achieve a more desirable index for the sample size ratio (Little et al., 2002), similar to the segmentation technique used by (Lee, Hallak and Sardeshmukh, 2016). Four parameters were created for the informal single-factor training criterion in this study.

The composite reliability value for the hidden variable of non-formal education of the four parameters in this study was 0.92 (Table 2). Aspects related to entrepreneurship education and human capital education transfer were evaluated using 7 factors (Nami et al.,2017). The combined reliability estimates for the hidden variables of training transfer and entrepreneurship training were 0.78 and 0.84 , respectively. The results showed four factors of entrepreneurship education and three factors of performance. The composite reliability of the second-order (two-factor) hidden human capital variable in this study was 0.85 (Table 2). Innovation was assessed using the following two factors, which were taken from the (Camisón and Monfort-Mir, 2012) Innovation Criterion: 1. Providing managerial innovation; and 2. Marketing innovation. Response options were within the Likert spectrum. The composite reliability for this latent variable of innovation was 0.72 (Table 2). Entrepreneurial self-efficacy was assessed using the 23-item scale developed by (De Noble, Jung and Ehrlich,1999). These factors were conceptualized as a multi-dimensional hidden structure with six dimensions: 1) new product development and market opportunities, 2) creating an innovative environment, 3) investor relations, 4) target setting, 5) tackling unexpected challenges and 6) Human resource development. All items were scored on a 5-point Likert scale.

Table 1

Factor analysis of structural measurement models

\begin{tabular}{|c|c|c|c|c|c|c|c|}
\hline IFI & CFI & RMSEA & SRMR & $\mathrm{p}$ & df & $\mathrm{X} 2$ & Model \\
\hline 0.93 & 0.93 & 0.07 & 0.07 & 0.001 & 154 & 241.27 & $\begin{array}{l}\text { Measurement model (List-based deletion; } \\
\mathrm{n}=27 \text { ) }\end{array}$ \\
\hline 0.90 & 0.90 & 0.08 & 0.12 & 0.001 & 160 & 354.70 & Hypothetical structural model \\
\hline 0.94 & 0.94 & 0.07 & 0.07 & 0.011 & 111 & 176.19 & Modified measurement model \\
\hline 0.94 & 0.94 & 0.07 & 0.07 & 0.003 & 112 & 188.31 & Modified structural model \\
\hline 0.95 & 0.95 & 0.07 & 0.07 & 0.003 & 112 & 188.04 & $\begin{array}{l}\text { Modified structural model (mean؛ } n= \\
35) 4\end{array}$ \\
\hline
\end{tabular}


Table 2

Validity of the measurement model

\begin{tabular}{|c|c|c|c|c|c|c|}
\hline 6 & 5 & 4 & 3 & 2 & 1 & Six variables related to the measurement model \\
\hline & & & & & 0.55 & Customer satisfaction (three factors; CR = 87) \\
\hline & & & & 0.62 & 0.27 & Financial performance (three factors; $\mathrm{CR}=85$ ) \\
\hline & & & 0.62 & 0.24 & 0.17 & Informal education (four parameters; $C R=92$ ) \\
\hline & & 0.64 & 0.36 & 0.31 & 0.36 & Human capital (two factors; $\mathrm{CR}=86$ ) \\
\hline & 0.50 & 0.51 & 0.29 & 0.30 & 0.57 & Innovation (two factors; $\mathrm{CR}=72$ ) \\
\hline 0000 & 0.05 & 0.10 & 0.01 & 0.00 & 0.01 & Entrepreneurial self-efficacy (one factor) \\
\hline
\end{tabular}

This table represents the composite reliability (CR) estimates for the five hidden variables of the model, the mean of the variance extracted by each of the five hidden variables of the model, and the square correlation variance between the six variables of the model of measurement as shown in Table 1, the model of the indicator The data fit well; and as shown in Table 2, all five CR values are above the threshold of 0.70 and all five AVE values are above the threshold and the corresponding squared correlations. Therefore, these results support the distinct uniformity and validity of the measurement model in the present study.

\section{Results}

In Table 3, the correlations of squared (R2) for non-formal education (three-way path), customer satisfaction (one-way path), performance (two-way path), as well as standard regression (SRW), standard error (SE), and estimates the importance of six structural paths related to the hypothesized structural model is shown. Figure 2 illustrates the hypothetical structural model associated with SRW and estimates of the importance of the six structural paths of the model. As shown in Table 3 and Figure 2, unlike H2 and H3, entrepreneurial innovation and self-efficacy were not positively correlated with non-formal education at the $\mathrm{p}<0.05$ level. In support of the H1 hypothesis, human capital was positively associated with non-formal education. In support of the H4 hypothesis, non-formal education was positively associated with customer satisfaction. In support of H5 hypothesis, informal organization training was positively related to business performance. 
Table 3

Structural paths of the hypothetical structural model

\begin{tabular}{|c|c|c|c|c|}
\hline $\mathrm{p}$ & $\mathrm{SE}$ & SRW & R2 & Final sample \\
\hline \multirow{4}{*}{ * } & & & 0.41 & Informal education of the organization \\
\hline & 0.20 & 0.54 & & Human capital $\leftarrow$ Informal education) $\mathrm{H} 1($ \\
\hline & & 0.30 & 0.31 & Innovation $\leftarrow$ Informal education) $\mathrm{H} 2($ \\
\hline & & 0.00 & 0.22 & Entrepreneurial self-efficacy $\leftarrow$ Informal education) $\mathrm{H} 3$ ( \\
\hline \multirow{5}{*}{$\begin{array}{l}* \\
*\end{array}$} & & & 0.18 & customer satisfaction \\
\hline & 0.14 & 0.38 & & .1Informal education $\leftarrow$ customer satisfaction) $\mathrm{H} 4($ \\
\hline & & & 0.35 & Financial performance of the organization \\
\hline & 0.12 & 0.31 & & (H5) Business financial performance $\leftarrow$ Informal education \\
\hline & 0.11 & 0.42 & & (H6) Business financial performance $\leftarrow$ Customer satisfaction \\
\hline
\end{tabular}

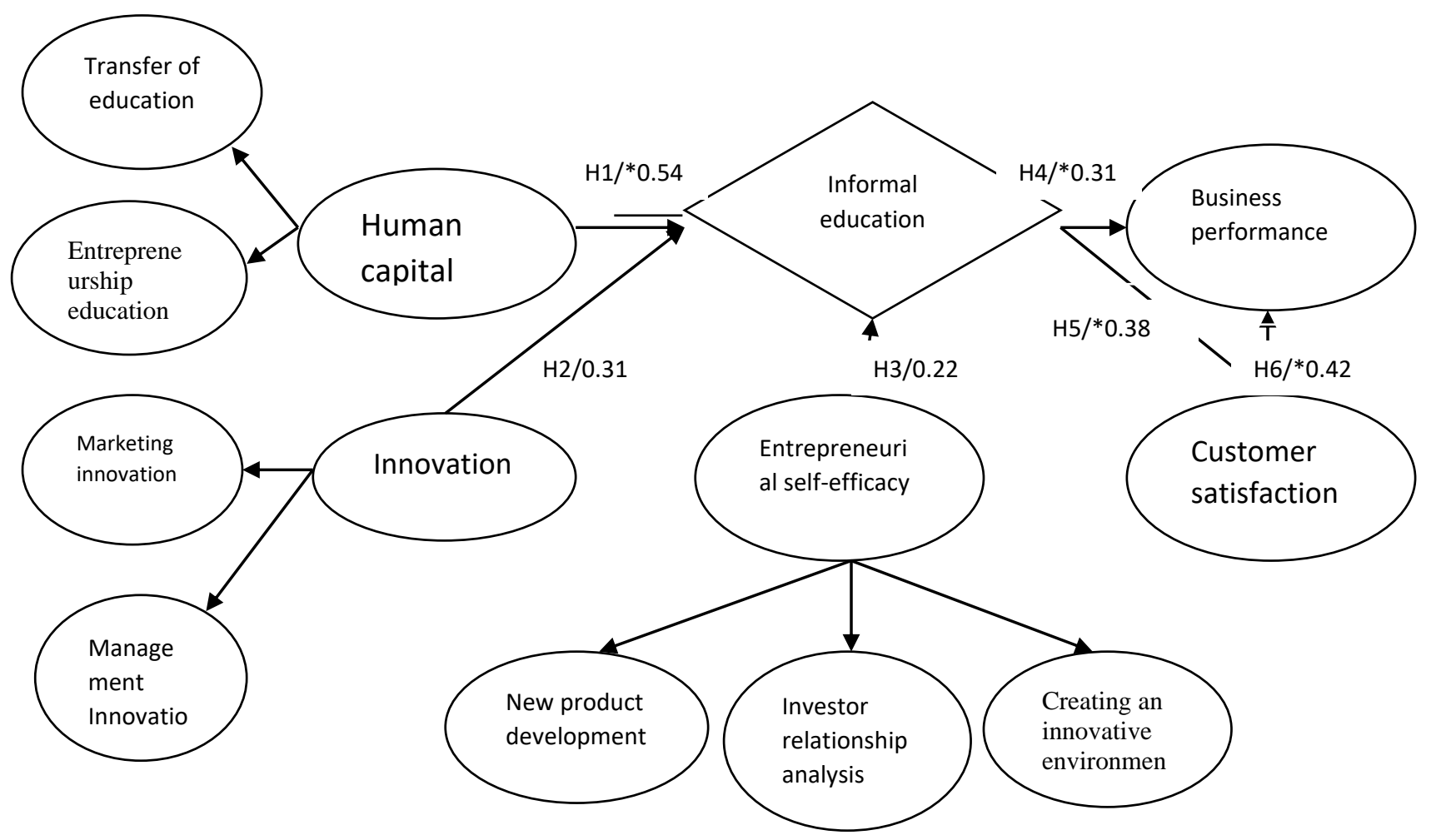

Fig. 2: Hypothetical structural model

As shown in Figure 2, in support of Hypothesis 3, there is a positive relationship between customer satisfaction and business financial performance. Given the indices of change in the 
assumed structural model and that the assumed structural model represents a moderate fit to the data (based on Table 1), and that organizational innovation and entrepreneurial self-efficacy do not correlate significantly with informal organization training (Table 3 and Figure 2) these two The variables were omitted (and a direct relationship between the organization's human capital and customer satisfaction was established) and the modified structural model is plotted in Figure 3.

Table 4

Structural paths of the modified structural model

\begin{tabular}{|c|c|c|c|c|}
\hline $\mathrm{P}$ & SE & SDE & $\mathrm{R} 2$ & List 80-based deletion \\
\hline \multirow{3}{*}{ ** } & & & 0.24 & Informal education of the organization \\
\hline & 0.17 & 0.49 & & Informal education $\leftarrow$ Human capital \\
\hline & & & 0.28 & customer satisfaction \\
\hline & 0.16 & -0.08 & \multirow{4}{*}{0.28} & customer satisfaction $\leftarrow$ Informal education \\
\hline$* *$ & 0.22 & 0.62 & & Customer satisfaction $\leftarrow$ Human capital \\
\hline$*$ & 0.12 & 0.25 & & $\begin{array}{l}\text { Financial performance of the organization } \\
\text { Business financial performance } \leftarrow \text { Informal education }\end{array}$ \\
\hline$* *$ & 0.11 & 0.44 & & $\begin{array}{l}\text { Business financial performance } \leftarrow \text { customer satisfaction } \\
\text { Mean }(\mathrm{n}=35)\end{array}$ \\
\hline \multirow{3}{*}{$* *$} & & & 0.25 & Informal education of the organization \\
\hline & 0.17 & 0.50 & & Informal education $\longleftarrow$ Human capital \\
\hline & 0.14 & -0.30 & 0.26 & $\begin{array}{l}\text { customer satisfaction } \\
\text { customer satisfaction } \leftarrow \text { Informal education }\end{array}$ \\
\hline$* *$ & 0.20 & 0.62 & \multirow{3}{*}{0.24} & customer satisfaction $\leftarrow$ Human capital \\
\hline$*$ & 0.10 & 0.27 & & $\begin{array}{r}\text { Business performance of the organization } \\
\text { Financial performance } \leftarrow \text { Informal education }\end{array}$ \\
\hline ** & 0.10 & 0.36 & & Financial performance $\leftarrow$ customer satisfaction \\
\hline
\end{tabular}

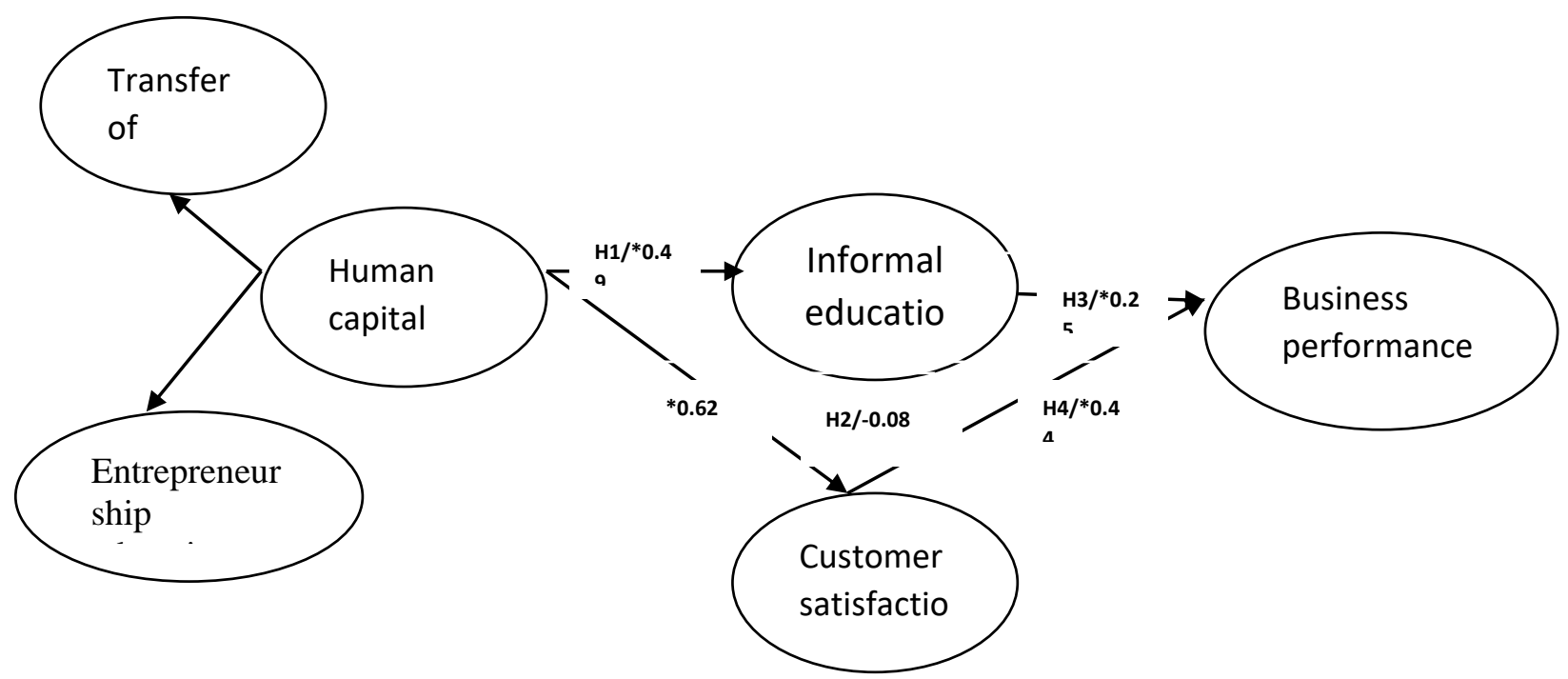


Fig. 3: Modified structural model

In Table 4, R2 estimates related to informal organization training (one structural path) customer satisfaction (two structural paths), financial performance (two structural paths) as well as standard direct effect (SDE), SE, significance estimates of model structural paths by elimination List-based 27 and average displacement of 35\% are shown. As shown in Table 4, the pattern of results for SDE, SE, and significance estimates for the five structural paths (and the fit indices of the modified structural model (Table 1) are similar), the similarity of these results shows that the index-based deletion provided the findings. In this paper they are not significantly affected (Way et al. 2018). In Figure 3, a modified structural model with SDE is shown and an estimation of the significance of 5 structural paths of the model is shown. In support of Hypothesis 1, human capital, Informal education affects the organization positively and directly, in contrast to attention

According to Hypothesis 2, informal training of the organization does not significantly affect customer satisfaction, while human capital of the organization positively affects customer satisfaction: informal training of organization (hypothesis 3) and customer satisfaction (hypothesis 4). Affects the financial of the organization positively, and the human capital of the organization has a positive, standard and indirect impact on the financial performance of the organization. Hypotheses 1, 3 and 4 were generally accepted, but Hypothesis 2 was not confirmed. However, it should be noted that the positive structural path between informal training of the organization andcustomer satisfaction in the assumed structural model (Fig. 2) is not meaningful when the structural path between organizational human capital and customer satisfaction in the modified structural model is considered (Fig. 3). This is the best result of the model being multi-linear; That is, the correlation between the human capital of the organization and the hidden variables of nonformal education in the present study.

\section{Discussion}

Based on a comparison of the research results of other authors, we finally came to the conclusion that the study of (Parsa et al., 2005) showed that education has an important effect on the performance of start-up businesses. And previous skills provide entrepreneurs with a useful understanding of how to identify markets. However, none of the previous studies has examined 
the relationship between human resources and the use of non-formal education. Also, according to the results (OttenBacher and Gnu, 2005).Managerial innovations can lead to new ways of organizing and provide staff training, development and rewards. However, no study has examined the relationship between business innovation and skills training.

According to previous studies, like the research of (Hallak, Lindsay, and Brown, 2011) have examined the relationship between ESE and performance at different levels. However, research on how ESE is structured on HR training is still unknown. An article (Cancedda et al., 2018) examined that human resource training can increase the competitiveness and financial performance of organizations, and this improves the performance of the organization. Based on the evidence obtained by (Wolfson et al.,2018) there is a positive relationship between informal training and organizational performance, and (Huselid, 1995) found that there is a positive relationship between strategic training and organizational financial performance? On the other hand, based on the results of research (Narayanan and Kaplan, 2001), it can be pointed out that human resource training can be used to turn fruitless relationships into profitable ones, and finally (Kim, Cho and Brymer, 2013) in research on they have come to the conclusion that customers are one of the key drivers of financial performance. In addition (Chi and Gursoy, 2009) concluded that customer satisfaction and financial performance of the organization are positively related. However, the effect of informal education in developing an entrepreneurial model that can lead new businesses has not been found in any research and is therefore one of the main reasons for writing this article.

Mohammadi and Dram (2018) conducted a study entitled The Role of Social Networks in Informal Education with the aim of investigating the role of social networks and social media in informal education. Non-formal education is an organized educational activity that provides women, men, children, youth, adults, the employed, the unemployed, the literate and the illiterate deprived of education with the aim of empowering them to develop their abilities. Informal torbat has different dimensions and types, about which different information was collected and presented in the present article by review and library methods. Then they introduced the most important harms that threaten non-formal education. Social networks were then discussed. Social networks are sites that offer their users the ability to share from a simple site such as a search engine with the addition of features such as chat and email and other features. At the end of the article, some suggestions were presented (Mohammadi and Drama, 2018). This study is consistent with the 
present study, but the limitations of this research are that it has done the discussion more theoretically and has not included field cases in its studies.

In 2015, Waqar Mousavi and Sobhani conducted a study entitled Model to Evaluate the Impact of Informal Entrepreneurship Training on Creating an Entrepreneurial Post. Studies the creation of entrepreneurial intent as moderating variables. In order to identify the latent variables and the relationships between them, structural equation modeling has been given using PLS software. Their research was of experimental skepticism type and data were collected as pretest, posttest and questionnaire. Findings show that applying the correct educational method in informal entrepreneurship courses, in addition to improving the level of skills required in learners, has a significant positive effect on creating an entrepreneurial position in them, as well as having the characteristics Entrepreneurial personality and desire to do related to entrepreneurship increases the effectiveness of these trainings in creating entrepreneurial intention (Waqar Mousavi and Sobhani, 2015). This study is consistent with the present study, but the limitations of their study were such that it seems that better results will be obtained when the SPSS program and the ANOVA or MANVO option are used as an intervention study.

Omran (2016) conducted a study entitled The role of informal learning in the development of key competencies in higher and vocational education environments. The main purpose of his research was to investigate the role of non-formal learning through social interactions in higher education and vocational education Jobs are key. The research method is survey and its statistical population is graduates of higher education and employed in the industries of Mazandaran province with a service record of 2-6 and the sample size is 150 people who have been selected by purposeful method. His research was conducted using a researcher-made questionnaire and interviews were conducted. The researcher has been used to determine the validity of the views of professors of educational sciences as well as the use of theoretical background and other research. Regarding reliability, it can be said that because the questionnaire used nominal variables and twochoice yes-no answers, the reliability coefficient could not be measured. The method of statistical analysis is through SPSS statistical software using descriptive statistics (frequency) and inferential statistics (chi-square test).

The results indicate that there is a significant difference between the role of higher education and the job environment in fostering key job competencies through informal learning resulting from social interactions, so that the role of higher education is greater. Personality and 
socio-communication competencies and in the work environment, personality and professional competencies are nurtured more than other competencies, respectively. Among the proposed components, informal learning through social interactions, the component of speech learning in the university and the component of behavioral learning in the work environment, have the highest frequency. It can be said that the greater number of good answers than yes answers indicates that none of the competencies are nurtured satisfactorily in any of the environments (Salehi Imran, 2016). This study is consistent with the present study, but the limitations of his research were that he did not calculate the alpha coefficient of the questionnaire he had created, so the questionnaire was not sufficiently valid.

\section{Conclusion}

The main conclusion of the paper is that non-formal education is considered as an intermediary between the human capital of the organization and the financial performance of the organization (Cadezand Guilding,2012) did not support the mediating effect of non-formal education on the relationship between human capital and corporate financial performance. However, the findings of the present study indicate that the underlying factors of industries may play an important role in determining the relationship. In addition, the findings of probability theory suggest that in order to increase the competitiveness and performance of an organization, organizational management systems (such as non-formal education) must be tailored to support human capital.

The findings of this study on the mediating effects of informal organization training and customer satisfaction on the relationship between organizational human capital and customer performance are based on the following empirical results: Organizational human capital on informal organization training (Hypothesis 1) and customer satisfaction have a positive and It has a direct effect; informal organization training (Hypothesis 3) and customer satisfaction (Hypothesis 4) have a positive and direct impact on the financial performance of the organization; and an organization's human capital has a positive and indirect impact on the financial performance of the organization. However, empirical evidence for Hypothesis 1 and Hypothesis 4 has been integrated with studies in which a negative and no significant relationship between financial performance and customer reported has been reported. 


\section{References}

Agarwa S, Erramilli MK, \&Dev, C. S. (2003). Market orientation and performance in service firms: role of innovation. Journal of Services Marketing17(1): 6882.https://www.researchgate.net/publication/241700779_Market_orientation_and_perform ance_in_service_firms_Role_of_innovation

Alonderienè, R (2010). Enhancing informal learning to improve job satisfaction: Perspective of SMEs managers in Lithuania.Baltic Journal of Management 5(2):257287.https://www.researchgate.net/publication/235278712_Enhancing_informal_learning_t o_improve_job_satisfaction_Perspective_of_SMEs_managers_in_Lithuania

Avcikurt, C, Altay, H, \&Oguzhan, IM (2011). Critical success factors for small hotel businesses in Turkey: an exploratory study. Cornell Hospitality Quarterly 52(2):153164.https://www.researchgate.net/publication/258130290_Critical_Success_Factors_for_S mall_Hotel_Businesses_in_Turkey_An_Exploratory_Study

Baker W. E, Grinstein, A,\&Harmancioglu, N (2016). Whose innovation performance benefits more from external networks: entrepreneurial or conservative firms? Journal of Product Innovation Management 33(1):104120.https://www.googleadservices.com/pagead/aclk?sa=L\&ai=DChcSEwiudDg263uAhUzgFAGHdmEDVoYABAAGgJkZw\&ae=2\&ohost=www.google.com\&cid= CAESQOD2TxmJfXs981vUiy9ZCT7FJQCkA9X8OFfnGFMZQcYoiISNru6cfZJYboZr71 tEGMHtvpquGN-C2UhIOEXVz-g\&sig=AOD64_1KgnI-

JR8UJL8PBHUbTiUjaa8AZg\&q\&adurl\&ved=2ahUKEwjzMXg263uAhUUXsAKHY9aBrYQ0Qx6BAgCEAE

Bandura, A. (1997). Self-efficacy: The exercise of control. New York:

Macmillan.http://scholar.google.com/scholar?q=Selfefficacy:+The+exercise+of+control.+New+York:+Macmillan\&hl=en\&as_sdt=0\&as_vis=1 \&oi=scholart

Banker, R. D., Potter, G.,\& Srinivasan, D. (2005). Association of nonfinancial performance measures with the financial performance of a lodging chain. Cornell Hotel and Restaurant 
Administration

Quarterly 46(4):394-

412.https://journals.sagepub.com/doi/10.1177/0010880405275597

Bernhardt, K. L., Donthu, N., \& Kennett, P. A. (2000).A longitudinal analysis of satisfaction and profitability. Journal of business research 47(2):161171.http://scholar.google.com/scholar?q=A+longitudinal+analysis+of+satisfaction+and+pr ofitability.+Journal+of+business+research\&hl=en\&as_sdt=0\&as_vis=1\&oi=scholart

Budianto, A. (2019). Customer Loyalty: Quality of Service. Journal of Management Review 3(1):299-

305.https://jurnal.unigal.ac.id/index.php/managementreview/article/view/1808

Bustinza, O. F., Gomes, E., Vendrell-Herrero, F., Baines, T. (2019). Product-service innovation and performance: the role of collaborative partnerships and $\mathrm{R} \& \mathrm{D}$ intensity. $R \& D$ Management, 49(1):33-45.https://onlinelibrary.wiley.com/doi/abs/10.1111/radm.12269

Cadez, S, \&Guilding, C (2012). Strategy, strategic management accounting and performance: a configurationally analysis. Industrial Management and Data Systems 112(3):484501.http://scholar.google.com/scholar?q=Strategy,+strategic+management+accounting+an $\mathrm{d}+$ performance:+a+configurationally+analysis.+Industrial+Management+and+Data+Syste ms\&hl=en\&as_sdt=0\&as_vis=1\&oi=scholart

Camisón, C., \&Monfort-Mir, V. M. (2012). Measuring innovation in tourism from the Schumpeterian and the dynamic-capabilities perspectives. Tourism management 33(4): 776789.http://scholar.google.com/scholar?q=Measuring+innovation+in+tourism+from+the+Sc humpeterian+and+the+dynamiccapabilities+perspectives\&hl=en\&as_sdt=0\&as_vis=1\&oi=scholart

Cancedda, C., Cotton, P., Shema, J., Rulisa, S., Riviello, R., Adams, L. V., Farmer, P. E., Kagwiza, J. N., Kyamanywa, P., Mukamana, D., \&Mumena, C. (2018). Health professional training and capacity strengthening through international academic partnerships: The first five years of the Human Resources for Health Program in Rwanda. International Journal of Health Policy and Management 7(11):1024.https://www.ijhpm.com/article_3524.html Capiez, A., \&Kaya, A (2004). Yield management and performance in the hotel industry. Journal of Travel and Tourism Marketing 16(4):21-31. https://www.tandfonline.com/doi/abs/10.1300/J073v16n04_05 
Chi, C. G., \&Gursoy, D. (2009). Employee satisfaction, customer satisfaction, and financial performance: An empirical examination. International Journal of Hospitality Management 28(2):245-

253.http://scholar.google.com/scholar?q=Employee+satisfaction,+customer+satisfaction,+ and+financial+performance:+An+empirical+examination.+International+Journal+of+Hosp itality+Management\&hl=en\&as_sdt=0\&as_vis=1\&oi=scholart

Choi, K., Kang, K. H., Lee, S.,\&Lee, K. (2011). Impact of brand diversification on firm performance: a study of restaurant firms. Tourism Economics 17(4):885903.http://scholar.google.com/scholar?q=Impact+of+brand+diversification+on+firm+perfo rmance:+a+study+of+restaurant+firms.+Tourism+Economics\&hl=en\&as_sdt=0\&as_vis=1 \&oi=scholart

Cooper, A. C., Gimeno-Gascon, F. J., \&Woo, C. Y. (1994). Initial human and financial capital as predictors of new venture performance. Journal of business venturing 9(5):371395.https://www.sciencedirect.com/science/article/pii/0883902694900132

Corley, E. A., Bozeman, B., Zhang, X., \&Tsai, C. C. (2019). The expanded scientific and technical human capital model: the addition of a cultural dimension. The Journal of Technology Transfer 44(3):681-699.https://link.springer.com/article/10.1007/s10961-017-9611-y

Currie, G., Tuck, P., \&Morrell, K. (2015). How hybrid managers act as canny customers to accelerate policy reform: A case study of regulator-regulate relationships in the UK's tax agency. Accounting, Auditing and Accountability Journal 28(8):12911309.http://wrap.warwick.ac.uk/67580/

Davidson, P., \&Honig, B. (2003). The role of social and human capital among nascent entrepreneurs. Journal of business venturing 18(3):301331.https://www.sciencedirect.com/science/article/pii/S0883902602000976

De Noble, A. F., Jung, D., \&Ehrlich, S. B. (1999).Entrepreneurial self-efficacy: The development of a measure and its relationship to entrepreneurial action. Frontiers of entrepreneurship research 19(1):73-87.http://scholar.google.com/scholar?q=Entrepreneurial+selfefficacy:+The+development+of+a+measure+and+its+relationship+to+entrepreneurial+acti on.+Frontiers+of+entrepreneurship+research\&hl=en\&as_sdt=0\&as_vis=1\&oi=scholart

Fuller, B., Liu, Y., Bajaba, S, Marler, L. E., \&Pratt, J. (2018). Examining how the personality, self-efficacy, and anticipatory cognitions of potential entrepreneurs shape their 
entrepreneurial intentions. Personality and Individual Differences 125:120125.https://www.sciencedirect.com/science/article/abs/pii/S0191886918300059

Ganotakis, P. (2012). Founders' human capital and the performance of UK new technology-based firms. Small Business Economics 39(2):495515.https://link.springer.com/article/10.1007/s11187-010-9309-0

Gillespie, J. J., Privitera, G. J., \&Gaspero, J. (2019). Biopharmaceutical Entrepreneurship, Open Innovation, and the Knowledge Economy. Journal of Innovation Management 7(2):5977.https://journalsojs3.fe.up.pt/index.php/jim/article/view/2183-0606_007.002_0005

Grissemann, U., Plank, A., \&Brunner-Sperdin, A. (2013). Enhancing business performance of hotels: The role of innovation and customer orientation. International Journal of Hospitality Management 33:347-

356.https://www.researchgate.net/publication/257118047_Enhancing_business_performan ce_of_hotels_The_role_of_innovation_and_customer_orientation

Hall, C. M. (2009). Innovation and tourism policy in Australia and New Zealand: never the twain shall meet. Journal of Policy Research in Tourism, Leisure and Events 1(1):218.https://www.tandfonline.com/doi/abs/10.1080/19407960802703466

Hallak, R., Assaker, G., \&Lee, C. (2015). Tourism entrepreneurship performance: The effects of place identity, self-efficacy and gender. Journal of Travel Research 54(1):3651.http://scholar.google.com/scholar?q=Tourism+entrepreneurship+performance:+The+eff ects+of+place+identity,+selfefficacy+and+gender.+Journal+of+Travel+Research\&hl=en\&as_sdt=0\&as_vis=1\&oi=sch olart

Hallak, R., Assaker, G., \&O’Connor, P. (2014). Are family and nonfamily tourism businesses different? An examination of the entrepreneurial self-efficacy-entrepreneurial performance relationship. Journal of Hospitality and Tourism Research 38(3):388413.https://journals.sagepub.com/doi/abs/10.1177/1096348012461545

Hallak, R., Lindsay, N. J., \&Brown, G. (2011). Examining the role of entrepreneurial experience and entrepreneurial self-efficacy on SMTE performance. Tourism Analysis 16(5):583599.http://scholar.google.com/scholar?q=).+Examining+the+role+of+entrepreneurial+expe rience+and+entrepreneurial+self- 
efficacy+on+SMTE+performance.+Tourism+Analysis\&hl=en\&as_sdt=0\&as_vis=1\&oi=sc holart

Ham, S., \&Lee, S. (2011). US restaurant companies' green marketing via company websites: impact on financial performance. Tourism Economics17(5):10551069.http://www.restaurantessostenibles.com/Uploads/docs/Cap\%2014.-

Green\%20Marketing\%20Restaurant\%20Ham\%20and\%20Lee\%20(2011).pdf

Hébert, R. F., \&Link, A. N. (2006).The entrepreneur as innovator. The Journal of Technology Transfer 31(5):589.https://econpapers.repec.org/RePEc:kap:jtecht:v:31:y:2006:i:5:p:589597

Heskett, J. L., \&Sasser, W. E. (2010). The service profit chain: From satisfaction to ownership, handbook of service science. Publisher $\quad$ Springer: 31.https://www.springer.com/gp/book/9781441916273

Huselid, M. A. (1995). The impact of human resource management practices on turnover, productivity, and corporate financial performance. Academy of management journal 38(3):635-672.https://journals.aom.org/doi/abs/10.5465/256741

Jogaratnam, G., Tse, E.C., \&Olsen, M. D. (1999). An empirical analysis of entrepreneurship and performance in the restaurant industry. Journal of Hospitality and Tourism Research 23(4):339-

353.https://www.researchgate.net/publication/247753288_An_Empirical_Analysis_of_Ent repreneurship_and_Performance_in_the_Restaurant_Industry

Kaplan, R. S., \&Norton, D. P. (2004). The strategy map: guide to aligning intangible assets. Strategy and leadership 32(5):1017.https://www.emerald.com/insight/content/doi/10.1108/10878570410699825/full/html

Kellermanns F, Walter J, Crook TR, Kemmerer B, Narayanan V (2016). The resource-based view in entrepreneurship: A content-analytical comparison of researchers' and entrepreneurs' views. Journal of Small Business Management 54(1):2648.https://www.researchgate.net/publication/256050276_The_ResourceBased_View_in_Entrepreneurship_A_ContentAnalytical_Comparison_of_Researchers'_and_Entrepreneurs'_Views

Kim WG, Cho M, Brymer RA (2013). Determinants affecting comprehensive property-level hotel performance: The moderating role of hotel type. International Journal of Hospitality 
Management 34:404-

412.https://www.sciencedirect.com/science/article/abs/pii/S0278431912001582

Lee C, Hallak R, Sardeshmukh SR (2016). Innovation, entrepreneurship, and restaurant performance: A higher-order structural model. Tourism Management 53:215228.https://www.sciencedirect.com/science/article/pii/S0261517715300169

Liao YC, Tsai KH (2019). Innovation intensity, creativity enhancement, and eco-innovation strategy: The roles of customer demand and environmental regulation. Business Strategy and the Environment 28(2):316326.https://www.researchgate.net/publication/327406935_Innovation_intensity_creativity_ enhancement_and_ecoinnovation_strategy_The_roles_of_customer_demand_and_environ mental_regulation

Little TD, Cunningham WA, Shahar G, Widaman KF (2002). To parcel or not to parcel: Exploring the question, weighing the merits. Structural Equation Modeling a Multidisciplinary Journal $9(2): 151-$

173.https://www.researchgate.net/publication/228079497_To_Parcel_or_Not_to_Parcel_E xploring_the_Question_Weighing_the_Merits

Lumpkin GT, Dess GG (1996). Clarifying the entrepreneurial orientation construct and linking it to performance. Academy of management Review 21(1):135172.http://scholar.google.com/scholar?q=Clarifying+the+entrepreneurial+orientation+cons truct+and+linking+it+to+performance.+Academy+of+management+Review\&hl=en\&as_s $\mathrm{dt}=0 \&$ as_vis $=1 \& \mathrm{oi}=\mathrm{scholart}$

Maritz A, Brown C (2013). Enhancing entrepreneurial self-efficacy through vocational entrepreneurship education programs. Journal of Vocational Education and Training 65(4):543-

559.http://scholar.google.com/scholar?q=Enhancing+entrepreneurial+selfefficacy+through +vocational+entrepreneurship+education+programs.+Journal+of+Vocational+Education+a nd+Training\&hl=en\&as_sdt=0\&as_vis $=1 \&$ oi $=$ scholart

Marsick VJ, Watkins KE (2001). Informal and incidental learning. New directions for adult and continuing education: 2001(89):2534.https://onlinelibrary.wiley.com/doi/abs/10.1002/ace.5 
Mohammadi, Seyed Taqi and Ebrahimi Dram, Fatemeh, 2018, The Role of Social Networks in Informal Education, Provincial Conference on the Role of Informal Education in EducationBased Curriculum (from Necessity to Commitment), Rasht ,, https://civilica.com/doc/808329

Moss Kanter R (1983). The change masters: corporate entrepreneurs at work. Boston: Cox and Wyman Ltd.https://www.amazon.co.uk/Change-Masters-Corporate-EntrepreneursWork/dp/0415084679

Nafukho FM, Hairston N, Brooks K (2004). Human capital theory: Implications for human resource development. Human Resource Development International 7(4):545551.http://scholar.google.com/scholar?q=Human+capital+theory:+Implications+for+huma n+resource+development.+Human+Resource+Development+International\&hl=en\&as_sdt $=0 \&$ as_vis $=1 \&$ oi $=$ scholart

Nambisan S, Wright M, Feldman M (2019). The digital transformation of innovation and entrepreneurship: Progress, challenges and key themes. Research Policy 48(8):103773.https://www.sciencedirect.com/journal/research-policy/vol/48/issue/8

Nami K, Abbaszadeh MM, Hassani M, Bazargan A (2017). Structural Modeling the Impact of Organizational Factors on Human Resource Development with the Mediating Role of Knowledge Management Process and Training Transfer Pattern. Quarterly Journal of Training and Development of Human Resources 4(14):7796.https://www.sid.ir/en/Journal/ViewPaper.aspx?ID=576866

Narayanan VG, Kaplan RS (2001). Measuring and managing customer profitability. J. Cost Manage 15 (5):515.http://scholar.google.com/scholar?q=Measuring+and+managing+customer+profitability .$+\mathrm{J} .+$ Cost+Manage \&hl=en\&as_sdt=0\&as_vis=1\&oi=scholart

Nelson RR, Phelps ES (1966). Investment in humans, technological diffusion, and economic growth. The American economic review 56(1/2):6975.http://scholar.google.com/scholar?q=Investment+in+humans,+technological+diffusion, +and+economic+growth.+The+American+economic+review\&hl=en\&as_sdt=0\&as_vis=1 \&oi=scholart

Nowiński W, Haddoud MY, Lančarič D, Egerová D, Czeglédi C (2019). The impact of entrepreneurship education, entrepreneurial self-efficacy and gender on entrepreneurial intentions of university students in the Visegrad countries. Studies in Higher Education 44(2):361- 
379.https://www.researchgate.net/publication/319214791_The_impact_of_entrepreneurshi p_education_entrepreneurial_self-

efficacy_and_gender_on_entrepreneurial_intentions_of_university_students_in_the_Viseg rad_countries

O'Dwyer M, Gilmore A, Carson D (2009). Innovative marketing in SMEs: an empirical study. Journal of Strategic Marketing 17(5):383396.http://scholar.google.com/scholar?q=Innovative+marketing+in+SMEs:+an+empirical+ study.+Journal+of+Strategic+Marketing\&hl=en\&as_sdt=0\&as_vis=1\&oi=scholart

Ottenbacher M, Gnoth J (2005). How to develop successful hospitality innovation. Cornell Hotel and Restaurant Administration Quarterly 46(2):205222.https://journals.sagepub.com/doi/10.1177/0010880404271097

Ottenbacher M, Harrington RJ (2007). The innovation development process of Michelin-starred chefs. International Journal of Contemporary Hospitality Management 19(6):444460.https://www.emerald.com/insight/content/doi/10.1108/09596110710775110/full/html

Ottenbacher, M. C., Harrington, R. J. (2009). Institutional, cultural and contextual factors: Potential drivers of the culinary innovation process. Tourism and Hospitality Research 9(3):235-249.https://journals.sagepub.com/doi/10.1057/thr.2009.8

Ottenbacher, M. C., Harrington, R. J. (2009). The product innovation process of quick-service restaurant chains. International Journal of Contemporary Hospitality Management 21(5):523-

541.https://www.researchgate.net/publication/235297422_The_Product_Innovation_Proces S_of_Quick-Service_Restaurant_Chains

Parsa, H. G., Self, J. T., Njite, D., \&King, T. (2005). Why restaurants fail. Cornell Hotel and Restaurant Administration Quarterly46(3):304322.https://journals.sagepub.com/doi/abs/10.1177/0010880405275598

Porter, M. E., \&Millar, V. E.(1985). How information gives you competitive advantage.http://scholar.google.com/scholar?q=How+information+gives+you+competitive + advantage \&hl=en\&as_sdt=0\&as_vis $=1 \&$ oi=scholart

Reichheld, F. F., \&Covey, S. R. (2006). The ultimate question: Driving good profits and true growth.Massachussetts, USA: Harvard Business School Press.https://www.google.com/search?sxsrf=ALeKk00ztr34VQA5viRyfJIYQ9mXFDlieQ: 
$1611257172447 \& q=$ The+ultimate+question:+Driving+good+profits+and+true+growth.+M assachusetts,+USA:+Harvard+Business+School+Press\&spell=1\&sa=X\&ved=2ahUKEwj4 vZ7b4K3uAhVOilwKHRP-B6oQkeECKAB6BAgBEC0

Rogers, E. M.(2003). Diffusion of innovations. New York: Free Presshttps://academic.oup.com/sf/article-abstract/41/4/415/2227721

Salehi Omran, Ebrahim, 2016, The role of informal learning in cultivating key competencies in higher and vocational education environments ,,,, https://civilica.com/doc/1014151

Schneider, B.(1991). Service Quality and Profits: Can You Have Your Cake and Eat. People and Strategy 14(2):151.http://search.ebscohost.com/login.aspx?direct=true\&profile=ehost\&sco pe $=$ site $\&$ authtype $=$ crawler $\&$ jrnl $=01998986 \& A N=7703015 \& \mathrm{~h}=5$ dimoU62txidSIqOrStNli3 zyORTXCB2r7uaKVVXyi\%2F\%2B6c0ZgkjB4TQn5xovjtXQ08nyJ\%2BArz4\%2F1KvxV cTI0CA\%3D\%3D\&crl=c

Schumpeter, J. A.(2010). Capitalism, socialism and democracy. London: Routledge.https://www.routledge.com/Capitalism-Socialism-andDemocracy/Schumpeter/p/book/9780415107624

Tang, G., Wei, L. Q., Snape, E., \&Ng, Y. C.(2015). How effective human resource management promotes corporate entrepreneurship: Evidence from China. The International Journal of Human Resource Management 26(12):15861601.https://www.researchgate.net/publication/274098972_How_effective_human_resourc e_management_promotes_corporate_entrepreneurship_evidence_from_China

Tornow, W. W., Wiley, J. W.(1991). Customer satisfaction: A supportive work environment and its financial costs. Human Resource Planning 14(2):117127.http://scholar.google.com/scholar?q=Customer+satisfaction:+A+supportive+work+env ironment+and+its+financial+costs.+Human+Resource+Planning\&hl=en\&as_sdt=0\&as_vis $=1 \&$ oi $=$ scholart

Way, S. A., Simons, T., Leroy, H., Tuleja, E. A. (2018). What is in it for me? Middle manager behavioral integrity and performance. Journal of Business Ethics 150(3):765777.https://www.researchgate.net/publication/303509915_What_is_in_it_for_Me_Middle_ Manager_Behavioral_Integrity_and_Performance

Waqar Mousavi, Majid and Sobhani, Abdolreza, 1394, Model for evaluating the impact of informal entrepreneurship training in creating an entrepreneurial post, Third International Conference on Accounting and Management, Tehran „, https://civilica.com/doc/442122 
Wolfson, M. A., Tannenbaum, S. I., Mathieu, J. E., \&Maynard, M. T.(2018). A cross-level investigation of informal field-based learning and performance improvements. Journal of Applied

Psychology 103(1):14.http://scholar.google.com/scholar?q=A+crosslevel+investigation+of +informal+field-

based+learning+and+performance+improvements.+Journal+of+Applied+Psychology\&hl= en\&as_sdt=0\&as_vis $=1 \&$ oi $=$ scholart

Zhang, H. Q., Ren, L., Shen, H., \&Xiao, Q.(2013). What contributes to the success of Home Inns in China? International Journal of Hospitality Management 33:425434.https://www.sciencedirect.com/science/article/abs/pii/S0278431912001454

Zhou, K. Z., Brown, J. R., \&Dev, C. S. (2009). Market orientation, competitive advantage, and performance: A demand-based perspective. Journal of business research 62(11):10631070.http://scholar.google.com/scholar?q=Market+orientation,+competitive+advantage,+a nd+performance:+A+demandbased+perspective.+Journal+of+business+research\&hl=en\&as_sdt=0\&as_vis=1\&oi=schol art 